\title{
FAKTOR-FAKTOR PENENTU KOMITMEN ORGANISASI KEPALA SMK (Studi Kasus pada SMK di Kota Medan)
}

\author{
Benyamin Situmorang \\ Fakultas Teknik Universitas Negeri Medan \\ email: benyaminsitumorang@gmail.com
}

\begin{abstract}
Abstrak: Penelitian ini bertujuan untuk mengetahui faktor-faktor penentu komitmen organisasi kepala SMK di Kota Medan, dan menentukan model teoretik yang dapat menggambarkan hubungan kausalistik antarvariabel laten yang menentukan komitmen organisasi kepala sekolah. Populasi penelitian sebanyak 152 orang dan sampel 110 yang diambil dengan teknik proportional random sampling. Data komitmen organisasi, budaya organisasi, kepemimpinan, komunikasi interpersonal, dan kepuasan kerja dijaring dengan menggunakan kuesioner model skala Likert. Uji persyaratan analisis mencakup uji normalitas data dan uji linieritas regresi, sedangkan untuk menguji hipotesis penelitian digunakan path analysis. Hasil penelitian menunjukkan bahwa kesepuluh hipotesis yang diajukan berpengaruh langsung terhadap hal-hal terkait yang dikaji. Berdasarkan penerimaan kesepuluh hipotesis penelitian, ditemukan suatu model teoretik yang menggambarkan struktur hubungan kausal antara variabel budaya organisasi, kepemimpinan, komunikasi interpersonal, kepuasan kerja, dan komitmen organisasi kepala SMK.
\end{abstract}

Kata Kunci: komitmen organisasi, budaya organisasi, kepemimpinan, komunikasi interpersonal, kepuasan kerja

\section{DETERMINING FACTORS OF THE VOCATIONAL SCHOOL PRINCIPALS' ORGANIZATION COMMITMENT \\ (A Case Study in Vocational Schools in Medan Municipality)}

\begin{abstract}
This study was aimed to reveal the determining factors of the vocational school principals' organization commitment in Medan Municipality, and to find out a theoretical model which could describe the causal relationship among the latent variables determining the principals' organization commitment. The population consisted of 152 principals and 110 principals were taken using the proportional random sampling as the sample. The data on the organization commitment, organization culture, leadership, interpersonal communication, and work satisfaction were collected using questionnaires with the Likert scale. The pre-analysis testing included the normality test and the linearity test, while the hypothesis was tested using the path analysis. The findings showed that the ten hypotheses were accepted. Based on this, a theoretical model which showed the causal relationship among the variables of the organization commitment, organization culture, leadership, interpersonal communication, and work satisfaction of the vocational school principals was developed.
\end{abstract}

Keywords: organization commitment, organization culture, leadership, interpersonal communication, job satisfaction

\section{PENDAHULUAN}

Berbagai upaya telah dilaksanakan pemerintah, dalam hal ini Kementerian Pendidikan dan Kebudayaan untuk meningkatkan mutu pendidikan pada umumnya dan pendidikan kejuruan pada khususnya. Namun, sampai saat ini belum menunjukkan peningkatan yang berarti. Sekolah menengah kejuruan sebagai lembaga pendidikan formal bertujuan untuk meningkatkan kecerdasan, pengetahuan, kepribadian, ahklak mulia, serta keterampilan untuk hidup mandiri dan mengikuti pendidikan lebih lanjut. Oleh karena itu, pendidikan kejuruan perlu diorganisir dan diarahkan pada pencapaian lima pilar, yaitu: (1) belajar untuk beriman dan bertaqwa kepada Tuhan Yang Maha Esa; (2) belajar un- 
tuk mengetahui (learning to know); (3) belajar untuk berbuat (learning to do); (4) belajar untuk hidup antarsesama secara berdampingan (learning together); dan (5) belajar untuk membentuk jati diri (learning to be) (PP 19 Tahun 2005).

Kepala sekolah sebagai ujung tombak pelaksanaan pendidikan memunyai tugas yang mencakup tiga bidang, yaitu: (1) tugas manajerial; (2) supervisi; dan (3) kewirausahaan (Dharma, 2008:9). Kompetensi manajerial kepala sekolah dalam memahami sekolah sebagai sistem yang harus dipimpin dan dikelola dengan baik, di ataranya adalah pengetahuan tentang manajemen. Manajemen berperan penting dalam pengelolaan pedidikan sebagaimana diungkapkan Usman (2008:10) bahwa 80 persen masalah mutu pendidikan disebabkan oleh manajemen.

Kepemimpinan kepala sekolah merupakan salah satu faktor yang dapat mendorong sekolah untuk mewujudkan visi, misi, dan sasaran sekolah melalui program-program yang dilaksanakan secara terencana dan bertahap. Kepala sekolah dituntut menguasai perilaku organisasi, khususnya mengenai budaya organisasi, kepemimpinan, komunikasi interpersonal, kepuasan kerja, dan komitmen organisasi.

Dalam upaya meningkatkan mutu pendidikan, pemerintah telah memberdayakan kepala sekolah sedemikian rupa serta otonomi yang memberi ruang gerak yang lebih luas untuk mengelola pendidikan. Namun, pada kenyataannya mutu pendidikan di Indonesia masih memrihatinkan. Laporan Badan Perserikatan Bangsa-Bangsa (PBB) untuk bidang pendidikan, United Nation Educational Scientific and Cultural Organization (UNESCO) menunjukkan bahwa peringkat Indonesia dalam hal pendidikan turun dari peringkat 65 untuk tahun 2010 menjadi peringkat 69 pada tahun 2011 di antara 127 negara di dunia. Posisi tersebut berada di bawah Malaysia dan Brunei Darussalam (Kompas.com, 3 Maret 2011).

Kepala Dinas Pendidikan Provinsi Sumatera Utara pernah mengungkapkan bahwa kualitas pendidikan di kota Medan sangat memrihatinkan. Hal ini dinilai dari lemahnya sarana dan prasarana serta bobot mutu pendidikan yang diusung oleh Kadis Pendidikan Provinsi
Sumatera Utara. Faktor penyebab rendahnya mutu pendidikan Sumatera Utara adalah masalah manajemen pengelolaan sekolah yang berkaitan erat dengan peningkatan mutu sekolah. Pada umumnya manajemen sekolah di Sumatera Utara belum mampu menggali secara maksimal seluruh potensi yang ada agar dapat bersinergi dalam mendukung proses kegiatan pembelajaran yang optimal (Bahrumsyah, 2009). Simanjuntak (2009:5) melaporkan bahwa hasil survei pada tahun ajaran 2006/2007: lulusan SMK Negeri Medan hanya 23\% yang bekerja di dunia usaha dan industri, salah satu faktor penyebab rendahnya daya serap lulusan SMK tersebut adalah kepemimpinan kepala sekolah.

Pada pertengahan November 2008, Stuart Weston, Co-PDBE3 (Proyek Decentralized Basic Education Three), proyek lima tahun yang dirancang oleh USAID Indonesia, berkunjung ke Binjai Sumatra Utara dan menyatakan bahwa kemajuan di bidang pendidikan di Sumatera Utara akan lebih berhasil jika semua pihak memunyai komitmen yang tinggi untuk bersamasama meningkatkan kualitas pendidikan. Sejak tahun 2009 Kepala Dinas Pendidikan Propinsi Sumatera Utara, Bahrumsyah menjelaskan banyak variabel yang berpengaruh dalam mewujudkan programnya. Salah satu di antaranya adalah memiliki komitmen dan tekad yang kuat untuk berhasil.

Hal itu menunjukkan bahwa para pengelola pendidikan, khususnya kepala sekolah belum memiliki komitmen dalam menuntaskan masalah mutu pendidikan di Sumatera Utara. Kepala Dinas Pendidikan Provinsi Sumatera Utara Syaiful Syafri pada acara USAID DBE3 menyatakan bahwa sebaik apa pun program yang telah disusun untuk meningkatkan kualitas siswa di sekolah, akan dapat berjalan dengan baik bila kepala sekolah memiliki komitmen perubahan, cinta pekerjaan, mampu bekerja sama dengan guru dan masyarakat sebagai wali siswa.

Menyikapi hal tersebut, Kepala Dinas Pendidikan Propinsi Sumatera Utara dalam Renstra 2010-2014 merumuskan visi: "Terwujudnya sistem pendidikan masyarakat Sumatera Utara yang berdaya saing dan berakhlak mulia," 
salah satu misinya adalah "meningkatkan profesionalisme pendidik dan tenaga kependidikan". Peningkatan profesionalisme kepala sekolah kejuruan termasuk juga dalam misi tersebut. Lebih lanjut diungkapkan bahwa untuk mewujudkan misi tersebut, sumber daya manusia di Sumatera Utara ditantang agar memiliki komitmen yang tinggi pada perubahan dan inovasi pembelajaran. Hal tersebut secara implisit menunjukkan pentingnya suatu penelitian yang berfokus pada perilaku kepala sekolah kejuruan khususnya.

Komitmen organisasi termasuk variabel yang mendukung keberhasilan manajer dalam menjalankan fungsi-fungsi manajemennya. Berdasarkan pengamatan yang dilakukan terhadap kepala sekolah kejuruan selama ini, faktor-faktor penyebab kegagalan kepala sekolah mengembangkan sekolahnya bukan hanya disebabkan oleh kurangnya fasilitas, namun lebih banyak disebabkan kegagalan dalam menjalankan fungsi-fungsi manajemennya, termasuk komitmen organisasinya.

Komitmen organisasi merupakan kekuatan keterlibatan karyawan dalam suatu organisasi (Colquit, Lepine, dan Wesson, 2009:67). Karyawan yang tinggal dengan organisasi untuk jangka waktu yang panjang cenderung jauh lebih berkomitmen kepada orgnisasi dari pada mereka yang bekerja dalam waktu yang lebih singkat. Pendapat yang senada dikemukakan Newstrom (2007:207) yang menyatakan bahwa komitmen organisasi merupakan "...the degree to which an employee identifies with the organizational and wants to continue actively participating in it". Komitmen organisasi menggambarkan sejauh mana karyawan mengenali organisasi yang mempekerjakannya, yang merupakan keinginan karyawan untuk berupaya besar dengan niatnya untuk tinggal dengan organisasi ataupun keterikatan dengan organisasi untuk waktu yang lama disertai partisipasi aktif.

Dalam hasil penelitian Colquit, LePine, dan Wesson yang berjdul Integrative Model of Organizational Behavior dijelaskan bahwa kepuasan kerja secara langsung memengaruhi komitmen organisasi. Budaya organisasi melalui mekanisme individu (kepuasan kerja) meme- ngaruhi komitmen organisasi. Komitmen organisasi yang tinggi yang dimiliki kepala sekolah untuk mencapai tujuan akan melahirkan ide-ide dalam mencapai visi dan misi sehingga menimbulkan nilai-nilai individu yang ingin memajukan sekolahnya. Dengan demikian, dapat disimpulkan bahwa komitmen organisasi kepala sekolah menengah kejuruan adalah bentuk keterikatan psikologis pada lembaga yang ditandai dengan kepercayaan dan penerimaan pada nilainilai lembaga serta karakteristik pendidikan kejuruan dan dorongan yang kuat melakukan usaha-usaha dalam mencapai visi dan misi serta keinginan yang kuat untuk mempertahankan eksistensinya.

Budaya adalah tingkah laku serta gejala sosial yang menunjukkan identitas dan citra suatu masyarakat. Colquitt, Lepine, dan Wesson (2009:7) mendefinisikan budaya organisasi sebagai a field of study devoted to understanding, explaining, and ultimately improving the attitudes and behaviors of individuals and groups in organization.

Budaya organisasi membahas, menjelaskan, dan secara luas mengembangkan sikap dan perilaku individu dan kelompok dalam organisasi. Robbins dan Judge (2009:585) mengemukakan tujuh karakteristik primer yang bersama-sama menangkap hakikat budaya organisasi: (1) inovasi dan pengambilan resiko; (2) perhatian terhadap detail; (3) orientasi hasil; (4) orientasi orang; (5) orientasi tim; (6) keagresifan; dan (7) kemantapan.

Setiap karakteristik tersebut berada pada kontinum dari rendah ke tinggi. Dengan menilai organisasi berdasarkan tujuh karakteristik tersebut, akan diperoleh gambaran gabungan atas budaya organisasi. Dengan demikian, dapat disimpulkan bahwa budaya organisasi adalah seperangkat nilai-nilai, norma, asumsi, kepercayaan, prinsip-prinsip, dan kebiasaan atau peraturan yang berlaku di dalam suatu organisasi yang mengatur dan mengarahkan perilaku anggota-anggotanya dalam upaya melakukan suatu pekerjaan dalam memecahkan masalah.

Kepemimpinan (leadership) adalah proses memengaruhi dan mendukung orang-orang untuk bekerja secara antusias demi ketercapaian 
tujuan (Newstrom, 2007:159). Pernyataan tersebut menunjukkan bahwa orang-orang yang dipimpin diharapkan bekerja secara sukarela dan antusias. Cara dan kiat untuk mengajak orang untuk bekerja secara sukarela dan antusias tersebutlah yang harus dimiliki oleh seorang pemimpin. Di pihak lain, Sutrisno (2009:232) menyatakan bahwa kepemimpinan adalah kemampuan untuk memengaruhi pihak lain melalui komunikasi, baik langsung maupun tidak langsung dengan maksud untuk menggerakkan orang-orang agar dengan penuh pengertian, kesadaran, dan senang hati bersedia mengikuti kehendak pimpinan tersebut. Dengan demikian, dapat disimpulkan bahwa kepemimpinan kepala sekolah adalah kemampuan menanamkan keyakinan, memberdayakan siswa, guru, pegawai, teknisi laboratorium/workshop dengan penuh perhatian dan pengarahan untuk memperoleh dukungan dari mereka untuk mencapai visi dan misi.

Komunikasi didefinisikan sebagai penyampaian atau pertukaran informasi dari pengirim kepada penerima, baik secara lisan, tertulis maupun menggunakan alat komunikasi (Sopiah, 2008:141). Newstrom (2007:45) mengatakan, "Communication is the transfer of information and understanding from one person to anthoter person". Perpindahan pengertian tersebut melibatkan lebih dari sekedar kata-kata yang digunakan dalam percakapan, tetapi juga ekspresi wajah, intonasi, titik putus vokal, dan sebagainya. De Vito (2005:4) mengemukakan bahwa suatu komunikasi interpersonal bisa efektif dengan memperhatikan indikator-indikator: (1) keterbukaan; (2) empati; (3) dukungan; (4) kepositifan; dan (5) kesetaraan. Dengan demikian, dapat disimpulkan bahwa komunikasi interpersonal kepala sekolah adalah proses pengiriman dan penerimaan pesan-pesan antara dua orang dalam rangka mensosialisasikan visi dan misi yang dapat mengubah sikap, pendapat atau perilaku bawahan dan bersifat dialogis serta arus balik terjadi secara langsung.

Kepuasan kerja adalah sikap yang ditunjukkan seseorang dalam merasakan pekerjaannya. Colquitt, Lepine, dan Wesson (2009:105) menegaskan bahwa kepuasan kerja adalah "as a pleasurable emotional state resulting from the appraisal of one's job or job experiences". Kepuasan kerja merupakan suatu keadaan emosional yang menyenangkan yang dihasilkan atas penilaian pekerjaan atau pengalaman kerja. Semakin banyak aspek-aspek dalam pekerjaan yang sesuai dengan keinginan individu tersebut, maka semakin tinggi tingkat kepuasan yang dirasakannya, demikian sebaliknya.

Mullins (2005:703) mengajukan dua cara untuk mengukur kepuasan kerja, yaitu dengan mengukur kesesuaian antara yang diharapkan organisasi dengan yang dicari individu dari pekerjaan, dan dengan cara mengukur kesesuaian keinginan individu dengan yang diterimanya dari organisasi. Dengan demikian, dapat disimpulkan bahwa kepuasan kerja kepala sekolah adalah pernyataan tercapainya suatu harapan ataupun sikap terhadap pekerjaan yang menimbulkan perasaan senang terhadap pelaksanaan pekerjaan.

Berdasarkan uraian di atas, tujuan penelitian ini adalah untuk mengetahui dan mengkaji: (1) pengaruh budaya organisasi terhadap kepemimpinan; (2) pengaruh budaya organisasi terhadap komunikasi interpersonal; (3) pengaruh kepemimpinan terhadap komunikasi interpersonal; (4) pengaruh budaya organisasi terhadap kepuasan kerja; (5)pengaruh kepemimpinan terhadap kepuasan kerja; (6) pengaruh komunikasi interpersonal terhadap kepuasan kerja; (7) pengaruh komunikasi interpersonal terhadap komitmen organisasi; (8) pengaruh kepuasan kerja terhadap komitmen organisasi; (9) pengaruh kepemimpinan terhadap komitmen organisasi; dan (10) pengaruh budaya organisasi terhadap komitmen organisasi.

\section{METODE}

Penelitian yang dilakukan adalah jenis survei, yaitu yang termasuk kategori penelitian yang menjelaskan hubungan kausal dan pengujian hipotesis. Penelitian dilaksanakan pada SMK di Kota Medan pada bulan Februari hingga Agustus 2012. Populasi penelitian ini seluruh kepala SMK di Kota Medan yang berjumlah 152 orang yang terdiri atas 12 orang Kepala SMK Negeri dan 140 orang Kepala SMK Swas- 
ta. Penentuan sampel berdasarkan rumus Slovin diperoleh sebesar 110 orang yang ditentukan dengan cara proportional random sampling.

Data dikumpulkan dengan menggunakan angket pilihan berganda model skala Likert, setelah terlebih dahulu diujicobakan. Pengujian hipotesis dengan analisis jalur setelah terlebih dahulu dilakukan uji persyaratan analisis, yaitu uji normalitas dengan statistik One-Sample Kolmogorov-Smirnov Test dan uji linieritas digunakan Analisis Variansi untuk tes linieritas regresi dengan taraf signifikansi $\alpha=0,05$.

\section{HASIL DAN PEMBAHASAN}

\section{Hasil}

Deskripsi data yang akan disajikan pada bagian ini meliputi data variabel Budaya Organisasi $\left(\mathrm{X}_{1}\right)$, Kepemimpinan $\left(\mathrm{X}_{2}\right)$, Komunikasi Interpersonal $\left(\mathrm{X}_{3}\right)$, Kepuasan Kerja $\left(\mathrm{X}_{4}\right)$, dan Komitmen Organisasi $\left(\mathrm{X}_{5}\right)$. Data tersebut merupakan hasil kuantifikasi jawaban- jawaban responden atas angket yang disebarkan kepada Kepala SMK sebagai sampel penelitian. Jumlah angket yang disebarkan sebanyak 110 set sesuai dengan jumlah sampel penelitian. Deskripsi data setiap variabel penelitian disajikan dalam rangkuman pada Tabel 1 .
Lewat analisis data dapat diketahui bahwa skor budaya organisasi Kepala SMK cenderung dalam kategori cukup, skor kepemimpinan Kepala SMK cenderung dalam kategori tinggi, skor komunikasi interpersonal Kepala SMK cenderung dalam kategori tinggi, skor kepuasan kerja Kepala SMK cenderung dalam kategori cukup, dan skor komitmen organisasi Kepala SMK cenderung dalam kategori tinggi.

Rangkuman Perhitungan Normalitas Kolmogorov-Simirnov Test ditunjukkan pada Tabel 2.

Rangkuman hasil perhitungan di atas menunjukkan bahwa sebaran keseluruhan data tidak menyimpang dari distribusi normal, dan hal itu berarti asumsi normalitas telah dipenuhi.

Rangkuman hasil perhitungan uji linieritas hubungan variabel eksogenus dengan variabel endogenus ditunjukkan pada Tabel 3 .

Hasil uji linearitas menunjukkan bahwa bentuk hubungan variabel eksogenus dengan variabel endogenus adalah linier sehingga asumsi linieritas telah terpenuhi.

Komputasi statistik koefisien korelasi dan koefisien jalru berikut pengujiannya diringkas pada Tabel 4.

Tabel 1. Deskripsi Data Variabel Penelitian

\begin{tabular}{|c|c|c|c|c|c|c|}
\hline & & $\mathrm{X} 1$ & $\mathrm{X} 2$ & $\mathrm{X} 3$ & $\mathrm{X} 4$ & $\mathrm{X} 5$ \\
\hline \multirow[t]{2}{*}{$\mathrm{N}$} & Valid & 110 & 110 & 110 & 110 & 110 \\
\hline & Missing & 0 & 0 & 0 & 0 & 0 \\
\hline \multicolumn{2}{|c|}{ Mean } & 96,1091 & 122,2636 & 141,8727 & 95,3000 & 149,6182 \\
\hline \multicolumn{2}{|c|}{ Median } & 97,0000 & 123,5000 & 142,0000 & 95,0000 & 151,0000 \\
\hline \multicolumn{2}{|c|}{ Mode } & 107,00 & 123,00 & 145,00 & 95,00 & 164,00 \\
\hline \multicolumn{2}{|c|}{ Std. Deviation } & 16,46311 & 12,91374 & 15,09366 & 9,46219 & 17,78206 \\
\hline \multicolumn{2}{|c|}{ Variance } & 271,034 & 166,802 & 227,819 & 89,533 & 316,202 \\
\hline \multicolumn{2}{|c|}{ Range } & 73,00 & 69,00 & 70,00 & 60,00 & 74,00 \\
\hline \multicolumn{2}{|c|}{ Minimum } & 53,00 & 76,00 & 105,00 & 74,00 & 106,00 \\
\hline \multicolumn{2}{|c|}{ Maximum } & 126,00 & 145,00 & 175,00 & 134,00 & 180,00 \\
\hline \multicolumn{2}{|c|}{ Sum } & 10572,00 & 13460,00 & 15606,00 & 10483,00 & 16458,00 \\
\hline \multicolumn{2}{|c|}{ Mean Ideal } & 84,00 & 90,00 & 105,00 & 81,00 & 108,00 \\
\hline \multicolumn{2}{|c|}{ Std. Deviation Ideal } & 18,67 & 20,00 & 23,33 & 18,00 & 24,00 \\
\hline \multicolumn{2}{|c|}{ Minimum Ideal } & 28,00 & 30,00 & 35,00 & 27,00 & 36,00 \\
\hline \multicolumn{2}{|c|}{ Maximum Ideal } & 140,00 & 150,00 & 175,00 & 135,00 & 180,00 \\
\hline
\end{tabular}


Tabel 2. Perhitungan Normalitas Kolmogorov-Simirnov Test

\begin{tabular}{|c|c|c|c|c|c|c|}
\hline & & $\mathrm{X} 1$ & $\mathrm{X} 2$ & $\mathrm{X} 3$ & $\mathrm{X} 4$ & X5 \\
\hline $\mathrm{N}$ & & 110 & 110 & 110 & 110 & 110 \\
\hline Normal Parameters ${ }^{\mathrm{a}, \mathrm{b}}$ & Mean & 96,1091 & 122,2636 & 141,8727 & 95,3000 & 149,6182 \\
\hline & Std. Deviation & 16,46311 & 12,91374 & 15,09366 & 9,46219 & 17,78206 \\
\hline Most Extreme Differences & Absolute &, 107 &, 128 & , 106 & ,092 & 089 \\
\hline & Positive & 059 &, 058 &, 074 & ,092 &, 065 \\
\hline & Negative &,- 107 &,- 128 &,- 106 &,- 070 &,- 089 \\
\hline Kolmogorov-Smirnov Z & & 1,121 & 1,345 & 1,107 & ,961 & ,930 \\
\hline Asymp. Sig. (2-tailed) & &, 162 &, 054 &, 172 & ,314 &, 352 \\
\hline
\end{tabular}

Tabel 3. Rangkuman Hasil Perhitungan Uji Linieritas Hubungan Variabel Eksogenus dengan Variabel Endogenus

\begin{tabular}{|c|c|c|c|c|c|c|c|}
\hline & \multirow{2}{*}{$\begin{array}{l}\text { Variabel Eksogen terhadap } \\
\text { Variabel Endogen }\end{array}$} & \multicolumn{3}{|c|}{ Uji Linieritas } & \multicolumn{3}{|c|}{ Uji Keberartian Regresi } \\
\hline & & $\mathrm{F}_{\mathrm{h}}$ & Sig. & Status & $\mathrm{F}_{\mathrm{h}}$ & Sig. & Status \\
\hline 1. & $\mathrm{X}_{1}$ dengan $\mathrm{X}_{2}$ & 0,864 & 0,682 & Linier & 38,705 & 0,004 & Signifikan \\
\hline 2. & $X_{1}$ dengan $X_{3}$ & 1,252 & 0,206 & Linier & 21,952 & 0,001 & Signifikan \\
\hline 3. & $X_{1}$ dengan $X_{4}$ & 0,655 & 0,920 & Linier & 22,056 & 0,001 & Signifikan \\
\hline 4. & $\mathrm{X}_{2}$ dengan $\mathrm{X}_{3}$ & 0,922 & 0,599 & Linier & 16,029 & 0,001 & Signifikan \\
\hline 5. & $\mathrm{X}_{2}$ dengan $\mathrm{X}_{4}$ & 0,816 & 0,747 & Linier & 19,789 & 0,001 & Signifikan \\
\hline 6. & $X_{3}$ dengan $X_{4}$ & 1,490 & 0,081 & Linier & 17,669 & 0,001 & Signifikan \\
\hline 7. & $\mathrm{X}_{3}$ dengan $\mathrm{X}_{5}$ & 1,022 & 0,454 & Linier & 33,119 & 0,001 & Signifikan \\
\hline 8. & $\mathrm{X}_{4}$ dengan $\mathrm{X}_{5}$ & 1,320 & 0,164 & Linier & 25,690 & 0,001 & Signifikan \\
\hline 9. & $\mathrm{X}_{2}$ dengan $\mathrm{X}_{5}$ & 1,049 & 0,422 & Linier & 32,268 & 0,001 & Signifikan \\
\hline 10. & $X_{1}$ dengan $X_{5}$ & 1,029 & 0,448 & Linier & 34,580 & 0,001 & Signifikan \\
\hline
\end{tabular}

Tabel 4. Komputasi Statistik Koefisien Korelasi dan Koefisien Jalur dan Pengujiannya

\begin{tabular}{|c|c|c|c|c|c|}
\hline $\begin{array}{l}\text { Nomor } \\
\text { Hipotesis }\end{array}$ & $\begin{array}{l}\text { Koefisien } \\
\text { Korelasi* }\end{array}$ & $\begin{array}{l}\text { Koefisien } \\
\text { Jalur }\end{array}$ & $\mathrm{t}_{\text {hitung }}$ & Signifikansi & Keterangan \\
\hline 1. & $m_{12}=0,514$ & $p_{21}=0,514$ & 6,221 & 0,001 & Jalur Berarti \\
\hline 2. & $r_{13}=0,411$ & $p_{\mathrm{B} 1}=0,307$ & 3,046 & 0,003 & Jalur Berarti \\
\hline 3. & $\eta_{z a}=0,359$ & $p_{32}=0,202$ & 2,000 & 0,048 & Jalur Berarti \\
\hline 4. & $n_{14}=0,412$ & $P_{41}=0,220$ & 2,153 & 0,034 & Jalur Berarti \\
\hline 5. & $r_{24}=0,394$ & $P_{42}=0,205$ & 2,050 & 0,043 & Jalur Berarti \\
\hline 6. & $r_{34}=0,375$ & $P_{43}=0,211$ & 2,246 & 0,027 & Jalur Berarti \\
\hline 7. & $r_{5 \mathbf{5}}=0,484$ & $p_{5:}=0,259$ & 3,003 & 0,003 & Jalur Berarti \\
\hline 8. & $\eta_{\overline{5}}=0,438$ & $P_{54}=0,173$ & 1,988 & 0,049 & Jalur Berarti \\
\hline 9. & $r_{25}=0,480$ & $p_{52}=0,213$ & 2,337 & 0,021 & Jalur Berarti \\
\hline 10. & $n_{1 \mathbf{5}}=0,492$ & $P_{\mathrm{B} 1}=0,206$ & 2,200 & 0,030 & Jalur Berarti \\
\hline
\end{tabular}

*Semua koefisien korelasi signifikan $\left\{\mathrm{t}_{\text {hitung }}\right.$ lebih besar dari $\left.\mathrm{t}_{\text {tabel }(5 \%)}=1,658\right\}$

Berdasarkan harga-harga koefisien korelasi dan koefisien jalur yang diperoleh dari hasil perhitungan, dapat digambarkan diagram jalur (path diagram) yang merupakan fixed mo- del atau model teoretik yang menggambarkan hubungan kausalistik antarvariabel penelitian yang menentukan komitmen organisasi kepala SMK seperti pada Gambar 1. 


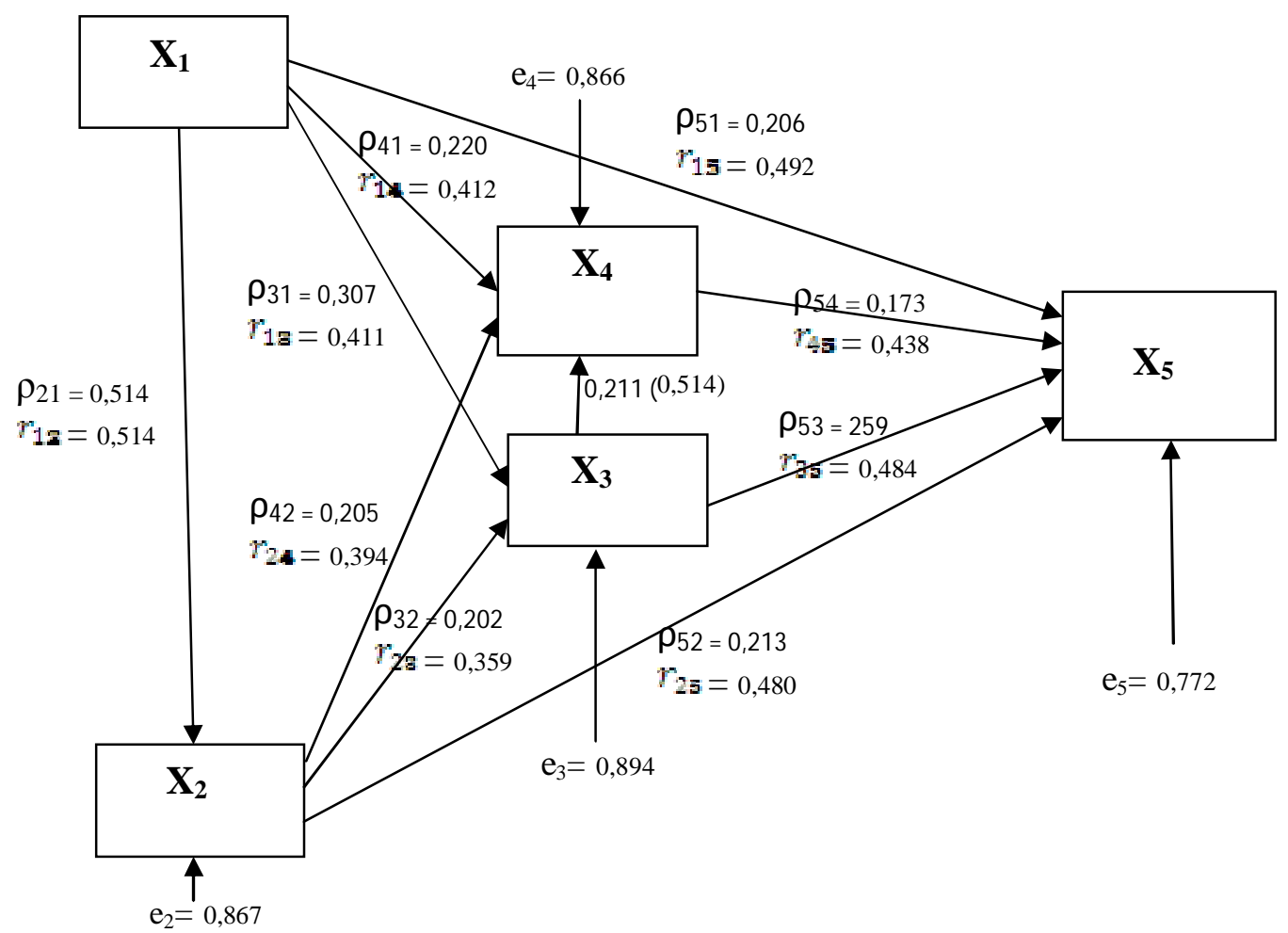

Gambar 1 Model Teoretik Variabel Penelitian

\section{Pembahasan}

Berdasarkan deskripsi data dan pengujian hipotesis, dilakukan pembahasan sebagai berikut. Pertama, budaya organisasi berpengaruh langsung positif terhadap kepemimpinan, dan besar pengaruhnya adalah 0,264. Temuan ini mendukung pendapat Newstrom (2007:26) yang menyatakan bahwa budaya organisasi berpengaruh langsung terhadap kepemimpinan, sebagaimana ditunjukkan dalam "An Organizational Behavioral System”. Keberhasilan kepemimpinan sebagian ditentukan oleh kemampuan pemimpin untuk mengembangkan budaya organisasi (Wirawan, 2007: 8).

Kedua, budaya organisasi berpengaruh langsung positif terhadap komunikasi interpersonal kepala SMK, dan besar pengaruhnya adalah 0,094. Mensosialisasikan budaya organisasi ini dengan komunikasi yang dijalin, baik secara vertikal maupun horizontal sehingga akan mengoptimalkan fungsi-fungsi budaya organisasi. Temuan ini mendukung pendapat Newstrom (2007:26) yang menyatakan budaya organisasi berpengaruh langsung terhadap komunikasi sebagaimana ditunjukkan dalam "An Organizational Behavioral System”.

Temuan penelitian ketiga menunjukkan bahwa kepemimpinan berpengaruh langsung positif terhadap komunikasi interpersonal kepala SMK, dan besar pengaruhnya adalah 0,041. Temuan penelitian ini mendukung pendapat Sutrisno (2011:232) yang menyatakan kepemimpinan adalah kemampuan untuk mempengaruhi pihak lain, melalui komunikasi baik langsung maupun tidak langsung dengan maksud untuk menggerakkan orang-orang agar dengan penuh pengertian, kesadaran, dan senang hati bersedia mengikuti kehendak pimpinan.

Temuan penelitian keempat menunjukkan bahwa budaya organisasi berpengaruh langsung positif terhadap kepuasan kerja kepala SMK dan besar pengaruhnya adalah 0,048. Temuan penelitian ini mendukung pendapat Colquit, Lepine, dan Wesson (2009:8) yang terkenal dengan Integrative Model of Organizational Behavior menjelaskan bahwa budaya organisasi berpengaruh langsung terhadap kepuasan kerja. Demikian juga pendapat Silverthone (2004:592-599) yang menyatakan bahwa 
kepuasan kerja dipengaruhi oleh nilai-nilai, norma ataupun asumsi yang merupakan cakupan budaya organisasi; serta penelitian Ambarita (2010:213) juga menyatakan bahwa budaya organsiasi berpengaruh langsung positif terhadap kepuasan kerja.

Temuan penelitian kelima menunjukkan bahwa kepemimpinan berpengaruh langsung positif terhadap kepuasan kerja kepala SMK, dan besar pengaruhnya adalah 0,042. Temuan penelitian ini mendukung pendapat Colquit, Lepine, dan Wesson (2009:8) yang menjelaskan bahwa kepemimpinan berpengaruh langsung terhadap kepuasan kerja. Temuan penelitian ini juga senada dengan penelitian yang dilakukan Filley, House, dan Kerr (2007:289) yang menyimpulkan bahwa para pemimpin yang memperhitungkan dan membantu pengikut-pengikutnya memunyai pengaruh yang positif terhadap sikap, kepuasan, dan pelaksanaan kerja. Selain itu, juga senada dengan penelitian Baihagi (2010:105); Darwito (2008:136), Ambarita (2010:212) yang menyimpulkan bahwa kepemimpinan berpengaruh langsung terhadap kepuasan kerja.

Temuan penelitian keenam menunjukkan bahwa komunikasi interpersonal berpengaruh langsung positif terhadap kepuasan kerja kepala SMK, dan besar pengaruhnya adalah 0,044. Temuan penelitian ini mendukung pendapat Sutrisno (2009:82) yang menyatakan bahwa komunikasi merupakan faktor yang memengaruhi kepuasan kerja. Adanya kesediaan pihak atasan untuk mendengar, memahami, dan mengakui pendapat ataupun prestasi bawahannya sangat berperan dalam menimbulkan rasa puas terhadap kerja. Temuan penelitian ini juga mendukung pendapat Sopiah (2008:172) yang menyatakan bahwa komunikasi interpersonal merupakan aspek kerja yang berpengaruh terhadap kepuasan kerja.

Temuan penelitian ketujuh menunjukkan bahwa komunikasi interpersonal berpengaruh langsung positif terhadap komitmen organisasi kepala SMK, dan besar pengaruhnya adalah 0,067 . Temuan penelitian ini mendukung pendapat Sopiah (2008: 164) dan Pertiwi (2011:82) yang menyatakan bahwa komunikasi interper- sonal mempengaruhi komitmen organisasi. Untuk menyampaikan maksud dan tujuan dari suatu organisasi, maka pimpinan akan berusaha mengkomunikasikannya sebaik mungkin agar bawahan ataupun orang yang terlibat di dalam organisasi tersebut dapat memahami.

Temuan penelitian kedelapan menunjukkan bahwa kepuasan kerja berpengaruh langsung positif terhadap komitmen organisasi kepala SMK, dan besar pengaruhnya adalah 0,03. Temuan penelitian ini mendukung penelitianpenelitian Colquit, Lepine, dan Wesson (2009: 8), Ambarita (2010:214) dan Guntur (2006:87) menjelaskan bahwa kepuasan kerja berpengaruh langsung terhadap komitmen organisasi. Kepuasaan kerja terbentuk berdasarkan pengalaman terhadap lingkungan pekerjaannya serta berdampak pada munculnya sikap atau tingkah laku tertentu, yaitu komitmen terhadap organisasi.

Temuan penelitian kesembilan menunjukkan bahwa kepemimpinan berpengaruh langsung positif terhadap komitmen organisasi kepala SMK, dan besar pengaruhnya adalah 0,045 . Temuan penelitian ini mendukung hasilhasil penelitian Darwito (2008: 139), Baihagi (2010:104), Desianty (2005:126), dan Ambarita (2010:212) yang menyimpulkan bahwa kepemimpinan berpengaruh langsung terhadap komitmen organisasi. Kepemimpinan pada dasarnya merupakan cara yang dilakukan pemimpin dalam mempengaruhi bawahannya untuk melakukan setiap kegiatan agar tercapai tujuan yang diharapkan.

Temuan penelitian kesepuluh menunjukkan bahwa budaya organisasi berpengaruh langsung positif terhadap komitmen organisasi kepala SMK dan besar pengaruhnya adalah 0,042. Temuan penelitian ini mendukung penelitian yang dilakukan O'Reilly, Chatman, dan Caldwell (2011:8) yang menyimpulkan bahwa kecocokan anggota organisasi dengan budaya yang berlaku dapat meningkatkan produktivitas, kepuasan dalam bekerja, performance, komitmen organisasi, dan keinginan untuk tetap tinggal di perusahaan. Selain itu, juga penelitian Nurjanah (2008:126) yang menyimpulkan 
bahwa budaya organisasi memunyai pengaruh total terhadap komitmen organisasi.

Berdasarkan temuan-temuan penelitian sebagaimana telah diuraikan di atas ditemukan suatu fixed model atau model teoretik yang menggambarkan hubungan kausalistik antarvariabel penelitian yang menentukan komitmen organisasi kepala SMK sebagaimana ditunjukkan pada Gambar 1.

\section{PENUTUP}

\section{Kesimpulan}

Berdasarkan hasil dan pembahasan sebelumnya, disimpulkan hal-hal seperti berikut. (1) Budaya organisasi berpengaruh langsung positif terhadap kepemimpinan kepala SMK di Kota Medan. (2) Budaya organisasi berpengaruh langsung positif terhadap komunikasi interpersonal kepala SMK di Kota Medan. (3) Budaya organisasi berpengaruh langsung positif terhadap kepuasan kerja kepala SMK di Kota Medan. (4) Kepemimpinan berpengaruh langsung positif terhadap komunikasi interpersonal kepala SMK di Kota Medan. (5) Kepemimpinan berpengaruh langsung positif terhadap kepuasan kerja kepala SMK di Kota Medan. (6) Komunikasi interpersonal berpengaruh langsung positif terhadap kepuasan kerja kepala SMK di Kota Medan. (7) Komunikasi interpersonal berpengaruh langsung positif terhadap komitmen organisasi kepala SMK di Kota Medan. (8) Kepuasan kerja berpengaruh langsung positif terhadap komitmen organisasi kepala SMK di Kota Medan. (9) Kepemimpinan berpengaruh langsung positif terhadap komitmen organisasi kepala SMK di Kota Medan. (10) Budaya organisasi berpengaruh langsung positif terhadap komitmen organisasi kepala SMK di Kota Medan.

\section{Implikasi}

Penerapan budaya organisasi perlu ditingkatkan secara sistematis serta konsisten melalui sikap dan perilaku yang mengarah pada peningkatan semangat kerja, loyalitas, disiplin, keterlibatan dan keberpihakan dalam organisasi, termasuk kesetiaan terhadap tugas serta menerima tujuan dan norma-norma yang berlaku, mematuhi peraturan, berperan aktif dalam kegiatan dan bertanggung jawab terhadap pekerjaan. Kepemimpinan yang sedang berlangsung perlu dipertahankan serta diupayakan peningkatannya dengan menggali pengetahuan tentang kepemimpinan, pelatihan kepemimpinan, workshop yang relevan secara intensif.

Kepala sekolah sebagai manajer dan pemimpin sekolah akan menjadi pemimpin yang sukses bila mampu memengaruhi bawahannya untuk mencapai tujuan. Untuk itu, kepala sekolah perlu: (1) merancang tugas yang hendak dilakukan; (2) memutuskan suatu cara untuk melakukan tugas tersebut; (3) memilih orang yang hendak melakukan tugas tersebut; (4) memberitahu mereka mengapa tugas tersebut harus dilakukan; (5) memberitahu mereka bagaimana cara mengerjakannya; dan (6) memberitahu mereka kapan tugas tersebut dilaksanakan.

Dalam rangka menjalankan tugas-tugas kepemimpinan kepala sekolah diperlukan komunikasi interpersonal, baik secara vertikal maupun horizontal dengan pola keterbukaan, berempati, kesetaraan, dan kepositifan.

Untuk meningkatkan kepuasan kerja dapat dilakukan dengan hal-hal seperti berikut. (1) Memberikan perhatian terhadap peningkatan karier/pangkat bagi kepala sekolah, sehingga berusaha melaksankan tugasnya dengan baik. (2) Memberikan penghargaan atau imbalan yang memadai, adil, dan berkesinambungan bagi kepala sekolah yang berprestasi. (3) Memberi pujian secara lisan maupun tertulis bagi kepala sekolah yang melakukan tugasnya dengan baik dan disiplin.

Untuk meningkatkan komitmen organisasi dapat dilakukan dengan upaya seperti berikut. (1) Memberi kesempatan dan bantuan dana kepada kepala sekolah untuk mengikuti pendidikan dan pelatihan yang berkaitan dengan tugas-tugas kekepalasekolahan. (2) Memberi kesempatan untuk meningkatkan pengetahuan dan kemampuan bagi kepala sekolah dengan memberi izin mengikuti pendidikan lanjutan. (3) Memberikan perhatian yang simpatik terhadap masalah-masalah yang dihadapi kepala sekolah, khususnya peningkatan karier atau kenaikan pangkat. 


\section{Saran}

Hendaknya kepala sekolah terus membenahi diri dengan memahami dan menghayati betapa pentingnya seorang pemimpin pendidikan memiliki komitmen organisasi, tidak hanya menjadikan sekolah yang dipimpin sebagai tempat kerja, tetapi menganggap sebagai bagian dari dirinya sehingga harus dirawat dan dipelihara agar tetap sehat dan berkembang. Untuk itu, kepala sekolah perlu mengevaluasi diri tentang budaya organisasi yang diterapkan, kepemimpinan yang dilaksanakan, komunikasi interpersonal yang digunakan, kepuasan kerja yang dirasakan, dan komitmen organisasi yang dilaksanakan. Hasil evaluasi diri ini hendaknya dibahas bersama dengan kepala sekolah lainnya dalam forum MKKS ataupun dengan para guru melalui diskusi-diskusi informal.

Kepala sekolah sebagai manajer dan pemimpin sekolah harus memiliki sifat-sifat yang menyenangkan semua orang yaitu: adil, suka melindungi, penuh inisiatif, penuh daya tarik, dan penuh percaya diri. Sifat adil mencerminkan tidak membedabedakan siapa disalahkan dan siapa yang dibenarkan, tidak ada anak emas, dan semuanya dihargai menurut jasa-jasa mereka. Sifat suka melindungi maksudnya suka mengayomi sehingga bawahan selalu merasa aman dan tenteram dalam perlindungannya. Sifat penuh daya tarik ditandai adanya keaktifan, kegembiraan, keramahan, keberanian, kejujuran, dan penuh vitalitas yang tinggi serta menarik simpatik. Sifat penuh percaya diri adalah menguasai persoalan yang dihadapi dan tahu cara penyelesaiannya.

Hendaknya pihak Dinas Pendidikan dan Kebudayaan memperlakukan jabatan kepala sekolah sebagai jabatan akademik dan bukan sebagai jabatan politis. Dengan demikian, dalam setiap pengangkatan kepala sekolah atas dasar keprofesionalan kekepalasekolahan. Selain itu, juga menghargai prestasi maupun hasil-hasil karya kepala sekolah sehingga termotivasi untuk berbuat yang lebih baik agar meningkatkan kepuasan kerjanya. Dinas Pendidikan juga diharapkan menyelenggarakan seminarseminar yang berkaitan dengan tugas ke-kepala sekolahan secara intensif, dan seminar hasilhasil penelitian tindakan sekolah.

\section{UCAPAN TERIMA KASIH}

Ucapan terima kasih disampaikan kepada: (1) Pimpinan Universitas Negeri Medan yang telah memberi kesempatan kepada saya untuk mengikuti Program Studi $\mathrm{S}_{3}$ Manajemen Pendidikan; (2) Pimpinan Program Pascasarjana Unimed yang telah memfasilitasi pelaksanaan penelitian dan penyelesaian disertasi; (3) Kepala Dinas Pendidikan Kota Medan beserta stafnya yang telah memfasilitasi pelaksanaan penelitian dan penyelesaian disertasi; (4) Promotor yang dengan tulus dan ikhlas membimbing pelaksanaan penulisan proposal disertasi hingga menjadi disertasi.

\section{DAFTAR PUSTAKA}

Ambarita, Biner. 2010. "Pengaruh Kepemimpinan, Manajemen Personalia, Budaya Organisasi, Kepuasan Kerja, dan Komitmen Organisasi terhadap Kinerja Dosen di Universitas Negeri Medan”. Disertasi. Program Pasca Sarjana Universitas Negeri Medan.

Bahrumsyah. 2009. "Kebijakan Dinas Pendidikan Propinsi Sumatera Utara dalam Meningkatkan Kompetensi Guru Bermuatan Soft Skill'. Makalah. Disampaikan dalam Seminar Internasional Universitas Negeri Medan, 10 Oktober 2009.

Baihagi, Muhammad Fauzan. 2010. "Pengaruh Gaya Kepemimpinan terhadap Kepuasan Kerja dan Kinerja dengan Variabel Komitmen Organisasi sebagai Variabel Intervening". Skripsi. Fakultas Ekonomi Universitas Diponegoro Semarang.

Colquitt, Jason A., Jeffery A. LePine, dan Michael J. Wesson. 2009. Organization Behavior: Improving Performance and Commitment in the Workplace. New York: The McGraw-Hill Com., Inc. 
De Vito, Joseph A. 2005. The Interpersonal Communication Book. New York: Harper \& Rew, Publisher.

Desianty, Sovya. 2005. "Pengaruh Gaya Kepemimpinan terhadap Komitmen Organisasi pada PT Pos Indonesia (Persero) Semarang. Jurnal Studi Manajemen dan Organisasi, 2 (1) Januari.

Dharma, Surya. 2008. Penilaian Kinerja Kepala Sekolah. Jakarta: Ditjen PMT Kemendiknas.

Darwito. 2008. "Analisis Pengaruh Gaya Kepemimpinan terhadap Kepuasan Kerja dan Komitmen Organisasi untuk Meningkatkan Kinerja Karyawan". Tesis. Semarang: Program Pascasarjana Universitas Diponegoro Semarang.

Mullins, Lauriel J. 2005. Management and Organizational Behavior. Edinburg Gate Harlow: Prentice Hall, Inc.

Newstrom, John W. 2007. Organizational Behavior, Twelfth Edition. New York: Mc Graw Hill.

Nurjanah. 2008. "Pengaruh Gaya Kepemimpinan dan Budaya Organisasi terhadap Komitmen Organisasi dalam Meningkatkan Kinerja Karyawan". Tesis. Program Pascasarjana Universitas Diponegoro Semarang.

Pertiwi, Rizki Wahyu Putri. 2011. "Pengaruh Kualitas Komunikasi Interpersonal terha- dap Komitmen Organisasional melalui Stres Kerja (Studi pada Karyawan PT. Rodasakti Suryaraya Malang)". Skripsi. Universitas Negeri Malang.

Robbins, Stephen, P. dan Timothy A. Judge. 2009. Organizational Behavior. New Jersey: Pearson Prentice Hall.

Silverthone, Colin. 2004. "The Impact of Organizational Culture and Person Organization Fit on Organizational Commitment and Job Satisfaction in Taiwan". The Leadership \& Organization Development Journal, 25, (7), 592-599.

Sopiah. 2008. Perilaku Organisasi. Yogyakarta: Penerbit C.V. Andi Offset.

Sutrisno, Edy. 2011. Budaya Organisasi. Jakarta: Penerbit Kencana.

Usman, Husaini. 2008. Manajemen Teori: Praktek dan Riset Pendidikan. Jakarta: Bumi Aksara.

Wirawan. 2007. Budaya dan Iklim Organisasi: Teori Aplikasi dan Penelitian. Jakarta: Salemba Empat.

Simanjuntak, Wanti. 2009. "Hubungan antara Struktur Inisiasi dan Konsiderasi dengan Efektivitas Kepemimpinan Sekolah Menengah Kejuruan (SMK) Negeri Kota Medan". Tesis (Medan: Sekolah Pascasarjana Universitas Negeri Medan. 